\title{
The Determinants of Profitability of Large-Scale and Small-Scale Turkish Deposit Banks
}

\author{
Pelin KAYA ${ }^{, b^{*}}$, Şenol BABUŞÇU ${ }^{\mathrm{a}}$, Adalet HAZAR ${ }^{\mathrm{a}}$ \\ a Prof. Dr. Başkent University, Department of Banking and Finance, Turkey \\ b PhD Student, Başkent University, Department of Banking and Finance, Turkey
}

\section{A B S T R A C T}

This paper aims to explore the bank-specific and macroeconomic determinants of the banks' profitability by dividing the Turkish deposit banks into large-scale and small-scale entities. For this purpose, panel data analysis was applied using fixed effects model, based on quarterly data for the period from March 2009 to September 2020 for 24 deposit banks. Return on assets and return on equity are used as a measure of the banks' profitability. According to the results, the determinants of profitability differ between large-scale banks and small-scale banks. With respect to the bank-specific determinants, the findings show that the equity/assets, deposits/assets and liquidity ratio have significant impact on the profitability of large-scale banks, whereas they have no relationship with the profitability of small-scale banks. The profitability of large-scale banks is negatively affected by their asset quality ratios. On the other hand, while the ratio of loans to total assets has no impact on the profitability of small-scale banks, the non-performing loan ratio has a positive impact. While the asset size and income-expense ratios have positive and significant impacts on the profitability of small-scale banks, they exhibit no relationship with the profitability of large-scale banks. With regard to macroeconomic indicators, small-scale banks' profitability is negatively affected by economic growth, whilst large-scale banks are not. This study is aimed to contribute to the literature by analysing the determinants of Turkish deposit banks' profitability under the classification of large-scale and small-scale banks.

\author{
ART I C L E I N F O \\ Keywords: \\ Bank Profitability, Determinants, \\ Large-Scale Banks, Small-Scale \\ Banks, Panel Data Analysis \\ *Corresponding author: \\ pcelik02@yahoo.com \\ (Pelin Kaya) \\ Article history: \\ Received 08.01.2021 \\ Revised 21.02.2021 \\ Accepted 24.03.2021 \\ DOI: \\ https://doi.org/10.51410/jcgirm.8.1.1
}

\section{INTRODUCTION}

The performance of a country's economy largely depends on the performance of its banking sector. Banks are financial intermediaries that are vitally important to economies. Banks, as financial intermediaries, have a vital role in the development of the economy in order to increase economic growth (Menicucci \& Paolucci, 2016). On the other hand, bank failures can lead to systemic crisis. Economies with profitable banking sectors are better able to withstand negative shocks and contribute to the stability of the financial system (Alper \& Anbar, 2011). Therefore, it is essential to understand the determinants of bank profitability.

In Turkey, most of the operations and activities in the money and capital markets are carried out by banks. Therefore, the banking sector is the most important mechanism for financing the economic 
growth in Turkey. The importance of bank risk management has been better understood with the financial crises experienced in 1994, 2000 and 2001 in Turkey. The Banking Sector Restructuring Program was put into practice in May 2001 in order to restore a healthy structure for banks whose financial structures and profitability performance deteriorated due to the November 2000 and February 2001 crises. Thanks to this program, public and private banks were restructured and the profitability and stability of the Turkish banking system was strengthened (BRSA, 2010).

Due to the new regulations introduced after the 2001 crisis, the impact of the 2008 global crisis on the Turkish financial sector has been limited and no serious deterioration was realized in the financial structure of the banking sector. In this context, thanks to the regulations implemented, banks were prevented from taking excessive risks and as a result the profitability of banks increased (BRSA, 2010).

While assessing the profitability of banks, it is important to consider the scale structure. Differences in banks' size scales can provide advantages or disadvantages for banks. Many articles explore the impact of bank size, measured by total assets, on profitability (Dietrich \& Wanzenried, 2011; Nguyen, 2020; Aladwan, 2015; Spathis et al., 2002; Özen \& Tetik, 2014). The findings of these studies imply that the bank size measured by total assets has a significant effect on profitability indicators.

This paper aims to assess the impact of bank-specific and macroeconomic determinants of profitability of the Turkish deposit banks under the classification of large-scale banks and small-scale banks. It is expected that this study makes a contribution to the literature by exploring the determinants of Turkish deposit banks' profitability under the said classification of banks. The study is based on quarterly data and covers the period between March 2009 and September 2020. This study is outlined as follows: Section 2 presents the literature review. Section 3 describes the factors determining the profitability of banks. In Section 4, the dataset and method are discussed. Section 5 focuses on analysis and findings. The last section covers the conclusion.

\section{LITERATURE REVIEW}

Almaqtari et al. (2018) examined the factors affecting the profitability of 69 commercial banks in the Indian banking sector, using panel data analysis during the period from 2008 to 2017. Profitability of Indian banks is measured by two indicators: return on assets (ROA) and return on equity (ROE). The results showed that bank size, number of branches, the ratio of operating income to assets, expenditure/revenue ratio and total debt to total assets ratio are the most important bank-specific determinants affecting the ROA of Indian banks. In addition, among the bank-specific determinants, bank size, operating income/assets ratio, asset quality ratio and liquidity ratio were found to have a significant positive effect on ROE. Regarding the macroeconomic determinants, it is concluded that inflation, exchange rate, interest rate and demonetisation have a significant impact on ROA, whereas all macroeconomic determinants excluding demonetisation have a significant effect on ROE. 
Ahmad et al. (2012) undertake a research to find out the profitability determinants of Pakistani local banks. As an indicator of profitability, ROA was used as a dependent variable whilst cost-income ratio, liquid assets/short-term funding, equity/assets and loan loss reserves/total gross loans were considered as independent variables. Panel data analysis was conducted for Pakistani local banks covering the period between 2001 and 2010. The results expressed a significant negative relationship between all these independent variables and ROA.

Batten \& Vo (2019) investigated the determinants of profitability for Vietnamese banks for the period between 2006 and 2014, using panel data analysis. Bank size, capital asset ratio, provisions to loans ratio and cost-income ratio are used as bank-specific independent variables. Inflation rate and GDP growth rate are used as macroeconomic variables. ROA, ROE and net interest margin are dependent variables to proxy for profitability. It has been found that these independent variables have strong impacts on profitability.

Paleni et al. (2017) examined the effect of the minimum capital adequacy ratio, loan/deposit ratio and the ratio of non-performing loans (NPL) to total loans on ROA for the period between 2011 and 2015 for rural banks in Indonesia using a multiple regression model. According to the results, all these variables have a positive and significant impact on ROA when used simultaneously. When evaluated separately, ROA was negatively affected by capital and loan to deposit ratios, and positively affected by NPL ratio.

Madugu et al. (2020) studied the impact of banks' capital adequacy and credit risk on profitability of foreign-owned and local banks in Ghana. The study was carried out using fixed effects estimation approach for 11 banks covering the years 2006 to 2016. The results showed that credit risk (NPLs / total assets) has a positive and stronger impact on the profitability of local banks compared to foreignowned banks. However, it was concluded that the capital adequacy ratio had no significant impact on the profitability indicators of local banks, whereas it had a negative impact on foreign banks' profitability.

Lee (2013) wanted to determine the determinants of the profitability of Korean banks under different banking regulatory regimes using the ordinary least squares (OLS) regression method. ROA is used as the proxy of banks' profitability. According to the results, while the profitability of Korean banks has a positive relationship with asset size and equity-to-assets ratio, it is negatively associated with the fixed asset ratio and NPL ratio. However, after the tightening of banking regulations with structural reforms in the aftermath of the Asian financial crisis, the positive relationship between profitability and asset size weakened, whilst the positive relationship between profitability and capital ratio strengthened.

Menicucci \& Paolucci (2015) investigated the bank-specific determinants of profitability in the European banking sector. Panel data analysis was applied to the 35 largest European banks over the period 2009 and 2013. Net interest margin, ROA and ROE are used as an indicator of profitability. The findings imply that bank size and capital ratio have significant positive impact on bank PAGE 3| Journal of Corporate Governance, Insurance, and Risk Management | 2021, VOL. 8, Series. 1 
profitability, while the increase in the ratio of loan loss provisions to total loans causes lower profitability levels.

In the study conducted by Bucevska \& Misheva (2017), ROE and ROA are used as bank profitability proxies. Bank assets to total banking sector, net interest income to average earning assets, cost efficiency, asset size, loan loss provisions to gross loans, equity to total assets, inflation rate and GDP growth rate are regarded as independent variables. The Generalized Moments Method was applied to find out the determinants of profitability for the years 2005 to 2009 for 127 commercial banks from 6 Balkan countries. According to the results, only the bank size is insignificant among the bank-specific variables, and the remaining variables affect the banks' profitability. On the other hand, it has been concluded that inflation and economic growth have no impact on profitability.

Sufian \& Habibullah (2009) investigated the determinants of profitability of 37 Bangladesh commercial banks between 1997 and 2004 using the unbalanced panel data model. Net interest margin ratio, ROE and ROA are used as dependent variables. The findings suggest that loans-to-asset ratio, credit risk, capital ratio and cost ratio have a significant and positive impact on bank profitability, whereas non-interest income to assets ratio has a negative impact. While asset size has a negative impact on ROE, it has a positive impact on ROA and net interest margin. When the macroeconomic variables are analyzed, it is concluded that only inflation has a significant and negative relationship.

Pervan et al. (2015) investigated the factors influencing bank profitability for the period between 2002 and 2010 using the dynamic panel model. ROA is used as the dependent variable as an indicator of bank profitability. Bank specific independent variables include bank size, market share, equity-toassets ratio (solvency), the ratio of loan provisions to total loans (credit risk), operating expenses, whilst macroeconomic variables are inflation rate and GDP growth. Except for market share, all variables have a significant impact on profitability. The variables that are statistically significant and have a positive impact on profitability are bank size, solvency and economic growth. Operating expenses, inflation and credit risk were statistically significant and had a negative impact on profitability.

Demirgüç-Kunt \& Huizinga (1999) investigated the determinants of profitability using net interest income to total assets and ROA as dependent variables using banking data from 80 countries for the years between1988 and 1995. While capital ratio is positively associated with profitability, provisions has a negative impact. Moreover, a positive relationship was found between real interest rate and inflation rate variables and profitability, especially in developing countries.

Saona (2016) evaluated the profitability determinants of seven Latin American commercial banks for the years 1995 to 2012 using the GMM approach. Net interest margin is used as the dependent variable. The results suggest that there is a negative relationship between revenue diversification (such as fees and commissions, interests) and profitability. Also, it is concluded that there is a positive relationship between market concentration and profitability. 
Dietrich \& Wanzenried (2011) conducted a profitability analysis of 372 commercial banks operating in Switzerland for the period between 1999 and 2009 using the GMM estimator technique. Net interest margin, ROE and ROA are used as dependent variables. Regarding the bank specific independent variables, the ratio of equity to total assets, cost-income ratio, the ratio of loan loss provisions to loans, the annual growth rate of deposits, bank size, difference between the growth in bank loan and average market growth of loans, the ratio of interest income to total income and the ratio of interest expenses to total deposits are used. GDP growth rate, maturity structure of interest rates and effective tax rate are used as macroeconomic independent variables. According to the results, there is no significant effect of capital ratio on bank profitability in the pre-crisis period between 1999 and 2006. On the other hand, in the post-crisis period of 2007 and 2009, a significant and negative effect was found on ROA. In the paper, cost-income ratio, funding costs and loan growth explain bank profitability. Further, profitability is affected by interest income, as well. Also, dummy variables are created for small, medium and large-scale banks to see the potential size effects. According to the results of the study, a negative effect of large-scale banks on profitability was found.

Alharbi (2017) examined the factors influencing the profitability of almost all Islamic banks in the world for the years between 1992 and 2008. Panel data method was applied using fixed-effects regression model in the study. Capital ratio, operating income, bank size, GDP per capita and oil prices positively affected the profitability of Islamic banks. Insurance system, oil prices and growth had a negative impact.

Pasiouras and Kosmidou (2007) analyzed the profitability determinants of 584 domestic and foreign deposit banks from 15 European Union countries for the period between 1995 and 2001. The findings show that bank specific variables, macroeconomic variables and financial market structure had significant impact on ROA.

Nguyen (2020) examined the effect of capital adequacy on banks' profitability in Vietnam. ROA and ROE are used as a measure of bank profitability. With the panel data regression analysis, 22 Vietnam banks were studied for the period 2010-2018, and while net interest margin, non-interest income and capital adequacy were positively associated with profitability variables, non-performing loans and public ownership were negatively related. In addition, by calculating the median, a distinction is made between small and large banks and the effect of capital adequacy on profitability is examined. While the effect of capital adequacy on ROA was positive for small banks, a significant relationship was not found for large banks.

Dizgil (2017) explores the impact of internal factors influencing the profitability of Turkish deposit banks. In this regard, panel data analysis was applied and the data of the 10 largest banks by asset size were used. ROA and ROE are considered as dependent variables in the analysis. According to the results of the study, a significant relationship was found between ROA and operating expenses ratio, capital adequacy ratio and financial asset to total asset ratio. Likewise, a significant relationship was 
found between ROE and operating expenses, capital adequacy ratio and liquid assets-to-total assets ratio.

Aladwan (2015) investigates the effect of bank size on the profitability of commercial banks with different size categories in Jordan. Using the data between 2007 and 2012, Jordanian commercial banks were divided into three categories according to their asset sizes. In the study, ROE is considered as a profitability indicator and used as a dependent variable. The results reveal that a significant difference has emerged in the profitability of banks of different size categories.

Spathis et al. (2002) divided Greek banks into two - large-scale and small-scale banks in terms of asset size and examined the effectiveness of Greek banks by using the ratios of ROA, ROE, net interest margin, liquidity, leverage, and capital adequacy. According to the results, large-scale banks were more efficient than small-scale banks.

\section{DETERMINANTS OF PROFITABILITY OF TURKISH DEPOSIT BANKS}

In accordance with the prior literature that explored the determinants of bank profitability, this study uses ROA and ROE as dependent variables (Almaqtari et al., 2018; 2013; Bucevska \& Misheva 2017; Nguyen 2020; Lee \& Kim, 2013; Dizgil, 2017). ROA consists of net profit divided by total assets, while ROE consists of dividing net profit by total equity. ROA demonstrates the efficiency of banks to generate earnings from its assets; and ROE is the return that investors earn from net assets.

Independent variables are examined in two groups as bank-specific and macroeconomic. Bankspecific variables are asset size, asset quality ratios, capital ratios, deposits and ratios regarding income and expense structure. Annual inflation rate and GDP growth rate are used as macroeconomic variables.

\subsection{Asset Size}

In most studies in finance literature, bank size is measured by total assets and calculated by taking the natural logarithm (LOGA) of the banks' total assets (Almaqtari et al., 2018; Batten \& Vo, 2019; Alper \& Anbar, 2011). This variable shows whether banks benefit from the advantages arising from economies of scale. If banks benefit from economies of scale, a positive relationship between bank size and profitability can be expected (Pasiouras \& Kosmidou, 2007). In many studies in the literature, one notes that asset size has a positive impact on bank profitability (Almaqtari et al., 2018; Lee, 2013; Menicucci \& Paolucci, 2015; Alharbi, 2017; Bucevska \& Misheva, 2017; Pasiouras \& Kosmidou, 2007; Pervan et al., 2015), whereas in Sufian \& Habibullah (2009), a negative relationship was found between asset size and profitability.

\subsection{Asset Quality Ratios}

In this study, three ratios are used as asset quality indicators. The first one is gross non-performing loans/total loans ratio (NPL). This ratio is an important credit risk indicator, and a high ratio weakens 
the credit quality. Nguyen (2020) found a negative relationship between the said ratio and profitability. There is also evidence from various studies showing a positive correlation between NPL ratio and profitability (Madugu et al., 2020; Paleni et al., 2017).

The second ratio used as an asset quality indicator is the loans-to-assets ratio (CRED). This ratio gives a measure of banks' income source and it is expected that profitability is affected positively unless the bank takes unbearable levels of risk. Some studies in the literature have found a negative relationship between profitability and loan ratio (Almaqtari et al., 2018; Staikouras \& Wood, 2004). On the other hand, a majority of the literature studies have found that loan ratio is positively related to bank profitability (Menicucci \& Paolucci, 2015; Pasiouras \& Kosmidou, 2007).

The third ratio used as an asset quality is fixed assets-to-total assets (FIX) ratio. Fixed assets are assets that do not have interest earnings. Although fixed assets are an important income source of loans, it is expected that the increase in the share of fixed assets in the balance sheet will negatively affect profitability (Lee, 2013; Demirgüç-Kunt \& Huizinga, 1999).

\subsection{Capital Ratios}

The regulatory capital adequacy ratio (CAR) is used to protect depositors and encourage the efficiency and stability of financial systems around the world and it helps to ensure the continuity of banks' activities against banking crises and significant losses. The ratio of equity to total assets (CAD) shows the strength of the bank's capital. If this ratio is high, it is expected that there will be less need for external funding, and it will result in higher profitability. In other words, banks' strong capital structure will reduce the default costs of banks and consequently result in a decrease in capital cost. These ratios show the bank's capacity to absorb losses. Based on the vast majority of the prior studies, a positive relationship is expected to be found between capital ratios and profitability (Almaqtari et al., 2018; 2013; Batten and Vo, 2019; Paleni et al., 2017; Lee, 2013; Menicucci \& Paolucci, 2015; Alharbi, 2017; Bucevska \& Misheva, 2017; Pervan et al., 2017; Demirgüç-Kunt \& Huizinga, 1999; Nguyen 2020).

\subsection{Deposit Ratio}

Deposits are seen as the major source of bank funding and its cost of funding is very low. Total deposits-to-total assets ratio (DEP) is used as an internal determinant in many prior studies (Almaqtari et al., 2018; Menicucci \& Paolucci, 2015). Menicucci \& Paolucci (2015) argue that the said ratio is positively related to profitability. As more deposits turn into loans, interest margins would rise, and banks will be able to generate further profits as a result.

\subsection{Liquidity}

Liquid assets-to-total assets ratio (LIQ) is used as a liquidity indicator (Dizgil, 2017). Inadequate liquidity is considered one of the main causes of bank failures. Strong liquidity enables banks to survive difficult times and creates flexibility for them. The funding structure and diversification of PAGE 7| Journal of Corporate Governance, Insurance, and Risk Management | 2021, VOL. 8, Series. 1 
banks are of great importance in terms of liquidity management. On the other hand, excessive liquidity can adversely affect bank profitability. Molyneux \& Thorton (1992) and Dizgil (2017) found a negative relationship between liquidity and profitability.

\subsection{Income - Expense Structure}

The ratio of net interest income to total assets (NIM) and the ratio of net non-interest income (noninterest income-non-interest expenses) to total assets (NII) are used to examine the income-expense structure (Saona, 2016; Almaqtari et al., 2018). A positive relationship with profitability is expected (Almaqtari et al., 2018; Bucevska \& Misheva, 2017; Nguyen 2020).

\subsection{Annual Inflation Rate}

The annual inflation rate (INF) calculates the percentage change in the Consumer Price Index (CPI) for all goods and services. Inflation affects the real value of income and expenses. If inflation cannot be predicted, the costs of the activities of banks may increase faster than their revenues, and as a result, profitability will be negatively affected (Pervan et al., 2015; Sufian \& Habibullah, 2009). Conversely, when the inflation rate is predicted, bank managers can increase profits by setting interest rates according to inflation. In Almaqtari et al. (2018), inflation rate has a negative impact on ROA but a positive impact on ROE. According to many literature studies, there is a positive relationship between inflation and profitability (Batten \& Vo, 2019; Dietrich \& Wanzenried, 2011; Demirgüç-Kunt \& Huizinga, 1999).

\subsection{Annual Real GDP Growth Rate}

While some studies in the literature show a positive GDP growth-profitability relationship (DemirgüçKunt \& Huizinga, 1999; Pervan et al., 2015; Pasiouras \& Kosmidou, 2007; Sufian \& Habibullah, 2009), some studies show a negative relationship (Almaqtari et al., 2018; Alharbi, 2017). As a result of the improvement in economic conditions, loan demands and solvency will increase, and the GDP growth rate will reflect positively on profitability. When the economic conditions deteriorate, the loan portfolios of the banks will weaken, and the profitability of the bank may be adversely affected as more provisions will be required for loans.

Table 1 shows the names of the variables, their explanations, and notations.

Table 1: Variables and Explanations

\begin{tabular}{|l|l|l|l|}
\hline & Variables & Explanations & Notation \\
\hline
\end{tabular}




\begin{tabular}{|c|c|c|c|}
\hline \multirow{2}{*}{ 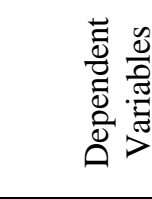 } & \multirow{2}{*}{ Profitability } & $\begin{array}{l}\text { Return on Assets = } \\
\text { Net Profit / Total Assets }\end{array}$ & ROA \\
\hline & & $\begin{array}{l}\text { Return on Equity = } \\
\text { Net Profit / Total Equity }\end{array}$ & $\mathrm{ROE}$ \\
\hline \multirow{10}{*}{ 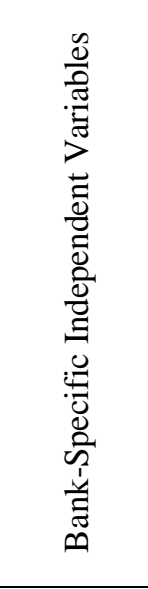 } & Asset size & Natural logarithm of total assets & LOGA \\
\hline & \multirow[t]{2}{*}{ Capital Adequacy } & $\begin{array}{l}\text { Regulatory Capital Adequacy Ratio = } \\
\text { Regulatory Capital / Risk Weighted Assets }\end{array}$ & CAR \\
\hline & & Equity / Assets & CAD \\
\hline & \multirow{3}{*}{ Asset Quality } & Loans / Assets & CRED \\
\hline & & Fixed Assets /Assets & FIX \\
\hline & & Non-performing loans (gross) / Total Loans & NPL \\
\hline & Deposit Ratio & Deposits / Assets & DEP \\
\hline & Liquidity & Liquid Assets / Assets & LIQ \\
\hline & \multirow{2}{*}{$\begin{array}{l}\text { Income - Expense } \\
\text { Structure }\end{array}$} & Net Interest Income / Total Assets & NIM \\
\hline & & Net Non-Interest Income / Total Assets & NII \\
\hline \multirow{2}{*}{ 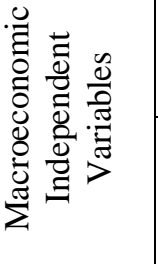 } & GDP Growth Rate & Annual Real GDP Growth Rate & GDP \\
\hline & Annual Inflation Rate & CPI (Annual \% Change) & INF \\
\hline
\end{tabular}

\subsection{Model}

In line with Sufian \& Habibullah (2009), Almaqtari vd. (2018), Nguyen (2020), Batten \& Vo (2019) and Pasiouras \& Kosmidou (2007), the following model is used to investigate the determinants of the profitability of Turkish deposit banks.

$$
\gamma_{i t}=\alpha_{i t}+\beta \times_{i t}+\epsilon_{i t}
$$

In the equation, $\mathrm{i}$ denotes deposit banks and $\mathrm{t}$ denotes years. $\mathrm{Y}_{\text {it }}$ designates the profitability of bank $\mathrm{i}$ at time $t, \alpha$ is the intercept term on independent variables, $X_{i t}$ is a vector of bank-specific and macroeconomic independent variables $i$ at time $t$ and $\varepsilon_{\mathrm{it}}$ is the error term.

\section{DATA AND METHOD}

This paper aims to find out the bank-specific and macroeconomic determinants of the banks' profitability by dividing the Turkish deposit banks into large-scale and small-scale banks. There are many studies in the literature that analyze the profitability determinants of banks in different bank size categories (Nguyen, 2020; Aladwan, 2015; Spathis et al., 2002; Kosmidou et al., 2006; Dietrich \& Wanzenried, 2011). In this study, the average of the banks' assets for the period between March 2009 and September 2020 is calculated and banks are divided into two (small and large) according to the 
median values of their average assets. Banks with a median value and below are considered as smallscale banks, while banks above the median value are considered as large-scale banks (Nguyen, 2020). Secondary data is used on a quarterly basis over a period ranging from March 2009 to September 2020 for 24 deposit banks, which have complete data for this period. According to the median calculation of average assets of banks over the period of March 2009 and September 2020, the first 12 banks with the highest asset size are under the large-scale bank classification and the remaining 12 banks are analyzed under the small-scale bank classification. The banks and scale groupings in the study are listed in Table 2:

Table 2: Banks in the Scale Groupings

\begin{tabular}{|l|l|}
\hline \multicolumn{1}{|c|}{ Large - Scale Banks } & \multicolumn{1}{c|}{ Small - Scale Banks. } \\
\hline Türkiye Cumhuriyeti Ziraat Bankası & Şekerbank. \\
\hline Türkiye Halk Bankası & Alternatifbank . \\
\hline Türkiye İş Bankası & Anadolubank. \\
\hline Türkiye Vakıflar Bankası T.A.O. & Fibabanka \\
\hline Türkiye Garanti Bankası. & ICBC Turkey Bank \\
\hline Yapı ve Kredi Bankası & Burgan Bank. \\
\hline Akbank & Citibank \\
\hline QNB Finansbank & Arap Türk Bankası \\
\hline Denizbank & Turkland Bank \\
\hline Türk Ekonomi Bankası & Turkish Bank \\
\hline ING Bank & Bank Mellat \\
\hline HSBC Bank & Habib Bank Limited \\
\hline
\end{tabular}

As of September 2020, the total asset size of the large-scale deposit banks in this study constitutes $88 \%$ of the total banking system assets, while the small-scale deposit banks account for $3.6 \%$, respectively.

The dataset for the bank-specific variables is obtained from the official website of the Banks Association of Turkey (TBB), while data on macroeconomic variables is fetched from the official web page of the Central Bank of the Republic of Turkey (CBRT). Panel data regression analysis is used in this study (Sufian \& Habibullah, 2009; Almaqtari et al., 2018; Ahmad et al., 2012; Batten \& Vo, 2019; Alharbi, 2017).

\section{DATA ANALYSIS AND FINDINGS}

PAGE 10| Journal of Corporate Governance, Insurance, and Risk Management | 2021, VOL. 8, Series. 1 
In this study, panel data analysis is used to investigate the determinants of profitability. In similar studies using panel data analysis, one notes that fixed effects or random effects models are generally used (Nguyen, 2020; Batten \& Vo, 2019; Dizgil, 2017; Alharbi, 2017; Alper \& Anbar, 2011).

In the analysis, firstly, a unit root test was conducted, and unit root isn't detected for any variables (Torres-Reyna, 2010). Then, the Hausman test was applied to choose between fixed effects and random effects models and the results suggest the use of fixed effects model (FEM) in all regressions. We also used the Breusch-Pagan and Breusch-Godfrey/Wooldridge tests to check for heteroskedasticity and autocorrelation respectively, and both problems were detected from the FEM model. Hence, Arellano estimators are applied for all the regressions (Torres-Reyna, 2010).

The panel regression results performed for large and small-scale banks where ROA and ROE are considered as dependent variables by using Arrelano estimators are given in tables 3 through 6 below.

Table 3: Determinants of ROA for Large-Scale Banks

\begin{tabular}{|l|r|r|r|r|}
\hline & Coefficients & $\begin{array}{r}\text { Standard } \\
\text { deviation }\end{array}$ & \multicolumn{1}{|c|}{$\mathbf{t}$} & \multicolumn{1}{|c|}{$\operatorname{Pr}(>|\mathbf{t}|)$} \\
\hline CAR & 0.0513 & 0.0353 & 1.4517 & 0.1472 \\
\hline CAD & 0.2473 & 0.0637 & 3.8825 & 0.0001 *** \\
\hline CEP & 0.0118 & 0.0073 & 1.6021 & 0.2787 \\
\hline FIX & -0.0339 & 0.0143 & -2.373 & $0.0180 *$ \\
\hline NPL & -0.1283 & 0.0334 & -3.838 & $0.0001 * * *$ \\
\hline LIQ & -0.1544 & 0.0384 & -4.023 & $6.58 \mathrm{e}-05$ *** \\
\hline NIM & -0.0081 & 0.0074 & -1.094 & 0.2744 \\
\hline NII & 0.0232 & 0.0239 & 0.970 & 0.3323 \\
\hline LOGA & 0.0796 & 0.0622 & 1.2798 & 0.2012 \\
\hline GDP & -0.0859 & 0.1814 & -0.474 & 0.6359 \\
\hline INF & -0.0107 & 0.0099 & -1.081 & 0.2800 \\
\hline R $^{2}$ & 0.0130 & 0.0084 & 1.5533 & 0.1209 \\
\hline F-statistic & 0.64 & Ajusted $\mathrm{R}^{2}$ & 0.62 & \\
\hline
\end{tabular}

Note: “.”, “*”, “**” and “***” denote significance level of $10 \%, 5 \%, 1 \%$ and 0,1\% respectively.

Table 4: Determinants of ROA for Small-Scale Banks

PAGE 11| Journal of Corporate Governance, Insurance, and Risk Management | 2021, VOL. 8, Series. 1 


\begin{tabular}{|l|r|r|r|r|}
\hline & Coefficients & $\begin{array}{r}\text { Standard } \\
\text { deviation }\end{array}$ & \multicolumn{1}{|c|}{$\mathbf{t}$} & \multicolumn{1}{c|}{$\operatorname{Pr}(>\mathbf{t} \mathbf{t})$} \\
\hline CAR & 0.0023 & 0.0146 & -0.1582 & 0.8743 \\
\hline CAD & 0.0224 & 0.0371 & 0.6039 & 0.5461 \\
\hline DEP & 0.0046 & 0.0073 & -0.6376 & 0.5240 \\
\hline CRED & -0.0008 & 0.0172 & -0.0466 & 0.9628 \\
\hline FIX & -0.2692 & 0.1538 & -1.7504 & 0.0806 \\
\hline NPL & 0.0030 & 0.0010 & 2.9185 & $0.0037 * *$ \\
\hline LIQ & -0.0010 & 0.0173 & -0.0551 & 0.9561 \\
\hline NIM & 0.2156 & 0.0792 & 2.7237 & $0.0067 * *$ \\
\hline NII & 0.3738 & 0.1255 & 2.9783 & $0.0030 * *$ \\
\hline LOGA & 0.3229 & 0.3279 & 0.9846 & 0.3253 \\
\hline GDP & -0.0335 & 0.0155 & -2.1607 & $0.0312 *$ \\
\hline INF & -0.0130 & 0.0428 & -0.3031 & 0.7619 \\
\hline R ${ }^{2}$ & 0.27 & Ajusted $\mathrm{R}^{2}$ & 0.24 & \\
\hline F-statistic & 16.35 & $\mathrm{p}$-value & $<2.22 \mathrm{e}-16$ & \\
\hline
\end{tabular}

Note: “.”, “*”, “**” and “***” denote significance level of $10 \%, 5 \%, 1 \%$ and $0,1 \%$ respectively.

Table 5: Determinants of ROE for Large-Scale Banks

\begin{tabular}{|l|r|r|r|r|}
\hline & Coefficients & $\begin{array}{r}\text { Standard } \\
\text { deviation }\end{array}$ & \multicolumn{1}{|c|}{$\mathbf{t}$} & \multicolumn{1}{|c|}{$\operatorname{Pr}(>|\mathbf{t}|)$} \\
\hline CAR & 0.3860 & 0.3793 & 1.0177 & 0.3093 \\
\hline CAD & 1.5328 & 0.7287 & 2.1035 & $0.0359 *$ \\
\hline CEP & 0.1482 & 0.0839 & 1.7658 & 0.0780 \\
\hline FIX & -0.4548 & 0.1466 & -3.1021 & $0.0020 * *$ \\
\hline NPL & -1.1669 & 0.3008 & -3.8791 & $0.0001 * * *$ \\
\hline LIQ & -1.6678 & 0.3590 & -4.6450 & $4.276 \mathrm{e}-06 * * *$ \\
\hline NIM & -0.1517 & 0.0658 & -2.3050 & $0.0215 *$ \\
\hline NII & 0.4326 & 0.2801 & 1.5444 & 0.1230 \\
\hline LOGA & 0.2590 & 0.6338 & 0.4086 & 0.6830 \\
\hline GDP & -0.4160 & 1.8258 & -0.2279 & 0.8198 \\
\hline INF & -0.1604 & 0.1054 & -1.5220 & 0.1286 \\
\hline R 2 & 0.0940 & 0.0754 & 1.2474 & 0.2128 \\
\hline
\end{tabular}

PAGE 12| Journal of Corporate Governance, Insurance, and Risk Management | 2021, VOL. 8, Series. 1 


\begin{tabular}{|l|r|r|r|r|}
\hline & Coefficients & $\begin{array}{r}\text { Standard } \\
\text { deviation }\end{array}$ & \multicolumn{1}{|c|}{$\mathbf{t}$} & \multicolumn{1}{|c|}{$\operatorname{Pr}(>|\mathbf{t}|)$} \\
\hline CAR & 0.3860 & 0.3793 & 1.0177 & 0.3093 \\
\hline CAD & 1.5328 & 0.7287 & 2.1035 & $0.0359 *$ \\
\hline DEP & 0.1482 & 0.0839 & 1.7658 & 0.0780. \\
\hline CRED & -0.4548 & 0.1466 & -3.1021 & $0.0020 * *$ \\
\hline FIX & -1.1669 & 0.3008 & -3.8791 & $0.0001 * * *$ \\
\hline NPL & -1.6678 & 0.3590 & -4.6450 & $4.276 \mathrm{e}-06 * * *$ \\
\hline LIQ & -0.1517 & 0.0658 & -2.3050 & $0.0215 *$ \\
\hline NIM & 0.4326 & 0.2801 & 1.5444 & 0.1230 \\
\hline NII & 0.2590 & 0.6338 & 0.4086 & 0.6830 \\
\hline F-statistic & 59.32 & $\mathrm{p}$-value & $<2.22 \mathrm{e}-16$ & \\
\hline
\end{tabular}

Note: “.”, “*”, “**” and “***” denote significance level of $10 \%, 5 \%, 1 \%$ and $0,1 \%$ respectively.

Table 6: Determinants of ROE for Small-Scale Banks

\begin{tabular}{|l|r|r|r|r|}
\hline & Coefficients & $\begin{array}{r}\text { Standard } \\
\text { deviation }\end{array}$ & \multicolumn{1}{c|}{ t } & \multicolumn{1}{|c|}{$\operatorname{Pr}(>|\mathbf{t}|)$} \\
\hline CAR & -0.2123 & 0.1664 & -1.2761 & 0.2025 \\
\hline CAD & 0.1102 & 0.3965 & 0.2780 & 0.7812 \\
\hline DEP & -0.0912 & 0.0777 & -1.1749 & 0.2405 \\
\hline CRED & 0.0278 & 0.1289 & 0.2154 & 0.8295 \\
\hline FIX & -2.2631 & 1.6390 & -1.3808 & 0.1679 \\
\hline NPL & 0.0049 & 0.0128 & 0.3849 & 0.7005 \\
\hline LIQ & 0.0092 & 0.1242 & 0.0744 & 0.9407 \\
\hline NIM & 2.0764 & 0.9414 & 2.2056 & $0.0278 *$ \\
\hline NII & 1.5194 & 0.7592 & 2.0014 & $0.0459 *$ \\
\hline LOGA & 4.5572 & 2.4895 & 1.8306 & 0.0677. \\
\hline GDP & -0.1328 & 0.0702 & -1.8924 & 0.0590. \\
\hline INF & -0.3562 & 0.3101 & -1.1489 & 0.2511 \\
\hline R ${ }^{2}$ & 0.23 & Ajusted $\mathrm{R}^{2}$ & 0,20 & \\
\hline F-statistic & 13.58 & $\mathrm{p}$-value & $<2.22 \mathrm{e}-16$ & \\
\hline
\end{tabular}

Note: “.”, “*”, “**” and “***” denote significance level of 10\%, 5\%, 1\% and 0,1\% respectively.

PAGE 13| Journal of Corporate Governance, Insurance, and Risk Management | 2021, VOL. 8, Series. 1 
As shown in Table 3 and Table 5, CAD is strongly significant at $0.1 \%$ and positively related to ROA of large - scale banks and it also works significantly at 5\% for ROE. In various studies, one notes that there is a significant and positive relationship between equity/asset ratio and bank profitability (Almaqtari et al., 2018; Batten \& Vo, 2019; Lee, 2013; Menicucci \& Paolucci, 2015; Alharbi, 2017; Pervan et al., 2015; Demirgüç-Kunt \& Huizinga, 1999). This positive relationship shows that banks with stronger capital adequacy can increase their profitability by decreasing their capital costs. On the other hand, one also finds that the CAD variable has no impact on the profitability of small-scale banks (Table 4 and Table 6).

There is a statistically significant positive relationship at the level of $10 \%$ between the DEP and ROE of large-scale banks (Table 5). This is consistent with the study of Menicucci and Paolucci (2015). There is no statistically significant impact of MEVD on the profitability of small-scale banks (Table 4 and Table 6). Hence, as more deposits turn into loans, interest margin and profit rise in large-scale banks.

There is a statistically significant and negative relationship between CRED and the ROA and ROE variables of large-scale banks at the level of 5\% and 1\% respectively (Table 3 and Table 5). According to the study of Menicucci \& Paolucci (2016), a too high loan-to-assets ratio could mean that banks grow their loan portfolios rapidly and pay a higher cost for their funding needs, and this can have a negative effect on profitability. A statistically significant relationship was not found between the CRED variable and the profitability of small-scale banks (Table 4 and Table 6).

The results in Table 3 and Table 5 demonstrate a highly significant and negative impact of FIX ratio on ROA and ROE of large-scale banks. At the same time, a negative relationship was found between the FIX variable and the ROA of small-scale banks at the $10 \%$ significance level (Table 4). This relationship is very weak compared to that in large-scale banks. Therefore, although fixed assets, which do not have interest income, are an important income source for loans, an increase in their share in the balance sheet negatively affects the profitability of large-scale banks (Lee, 2013; DemirgüçKunt \& Huizinga, 1999).

NPL ratio is negatively correlated with ROA and ROE of large-scale banks at a significance level of 0.1\% (Table 3 and Table 5). Higher NPL will require banks to allocate more resources for loan loss provisions and will result in lower returns on assets by increasing the bank cost (Nguyen, 2020). On the other hand, a statistically significant and positive relationship was found between the ROA of small-scale banks and NPL ratio at the $1 \%$ significance level (Table 4). This situation may arise from the loan interest rates applied by small banks (Madugu, 2020). Thus, high credit risk increases the profitability of small-scale banks while decreasing the profitability of large-scale banks.

LIQ ratio has a negative impact on ROE on large-scale banks at significance level of 5\% (Table 5). The study results of Molyneux \& Thorton (1992) and Dizgil (2017) revealed a negative relationship between liquidity ratio and profitability. LIQ has no significant relation with the profitability of small- 
scale banks (Table 4 and Table 6). Therefore, large-scale banks' excessive liquid asset holding may adversely affect their profitability.

While NIM and NII ratios have no impact on the profitability of large-scale banks, there is a strong positive relationship between the said variables and the ROA and ROE of small-scale banks, at $1 \%$ and 5\% significance level respectively. The positive relationship was also found in the Nguyen (2020) study. Hence, as the operational efficiency of small-scale banks increases, their profitability also increases.

There is a weak positive relationship between LOGA variable and ROE of small-scale banks at the $10 \%$ significance level (Table 6). On the other hand, this variable has no impact on the ROA of smallscale banks and on the ROA and ROE of large-scale banks. This result shows that small-scale banks benefit from the advantages arising from economies of scale (Pasiouras \& Kosmidou, 2007).

No significant relation was found between the GDP variable and the profitability of large-scale banks (Table 3 and Table 5). However, GDP is negatively correlated with ROA and ROE of small-scale banks at the 5\% and 10\% significance level respectively (Table 4 and Table 6). Almaqtari et al. (2018) and Alharbi (2017) also found a similar negative relationship in their studies.

\section{CONCLUSION}

This paper aims to explore the bank-specific and macroeconomic determinants of the banks' profitability by dividing the Turkish deposit banks into large-scale and small-scale entities. The study used the fixed effects panel quarterly data from March 2009 to September 2020 for 24 deposit banks, which have complete data for this period. The asset median size was calculated and the banks above the median value were classified as large-scale banks and the remaining banks were considered as small-scale banks.

The results show that the determinants of profitability differ between large-scale and small-scale banks. Regarding the impact of bank-specific determinants, while the profitability indicators of largescale banks are positively related to capital/assets and deposits/assets ratios, these variables have no impact on the profitability of small-scale banks. Furthermore, in large-scale banks, loans/assets and non-performing loans/total loans ratios have a negative impact on both profitability indicators, and there is a negative impact of liquidity ratio on ROE. On the other hand, in small-scale banks, nonperforming loans have a positive impact on ROA and loans to assets and liquidity ratio have no impact on both profitability indicators. Another finding of this study is that the ratio of fixed assets to total assets is more effective on the profitability indicators of large-scale banks than small-scale banks and there is a negative relationship. While the ratios of net interest income to total assets and net noninterest income to total assets have no impact on the profitability of large-scale banks, it is observed that they have a positive and strong impact on the profitability of small-scale banks. Regarding the macroeconomic determinants, the results revealed that GDP growth rate has no impact on the 
profitability of large-scale banks, whereas it has a negative and significant impact on the profitability of small-scale banks.

The findings of this study have important contributions to the literature by analysing the determinants of Turkish deposit banks' profitability under the classification of large-scale and small-scale banks. The results of this study are considered to be beneficial for bankers, regulators, analysts and academics.

Although this study covers most of the deposit banks operating in Turkey and takes into consideration the most important bank-specific and macroeconomic determinants of profitability, there are some limitations due to data constraints. Including additional aspects, such as off-balance sheet transactions, interest rate and currency risks into the analysis will help to better understand the determinants of bank profitability. In addition, it may be efficient and important in understanding bank profitability to integrate certain information about board members into the work, such as education and experience. Therefore, it is thought that the effects of these variables can form a basis for future studies.

\section{REFERENCES}

Ahmad, S., Nafees, B. and Khan, A. (2012), “Determinants of Profitability of Pakistani Banks: Panel Data Evidence for the Period 2001-2010”, Journal of Business Studies Quarterly, 4 (1), 149-165 Aladwan, M. S. (2015), “The Impact of Bank Size on Profitability: An Empirical Study on Listed Jordanian Commercial Banks”, European Scientific Journal, 11 (34), 217-236.

Alharbi, A. T. (2017), “Determinants of Islamic Banks’ Profitability: International Evidence”, International Journal of Islamic and Middle Eastern Finance and Management, 10 (3), 331-350.

Almaqtari, F. A., Al-Homaidi, E.A., Tabash M. I. and Farhan, Najib H. (2019), "The Determinants of Profitability of Indian Commercial Banks: A Panel Data Approach”, International Journal of Finance and Economics, 24 (1),168-185.

Alper, D. and Anbar, A. (2011), "Bank Specific and Macroeconomic Determinants of Commercial Bank Profitability: Empirical Evidence from Turkey”, Business and Economics Research Journal, 2 (2), 139-152.

Banking Regulation and Supervision Agency-BRSA (2010). "Krizden İstikrara Türkiye Tecrübesi”, available at: https://www.bddk.org.tr/ContentBddk/dokuman/duyuru_0395_02.pdf (accessed 1 November 2020).

Batten, J. and Vo, X. V. (2019), "Determinants of Bank Profitability-Evidence from Vietnam”, Emerging Markets Finance \& Trade, 55 (6), 1417-1428.

Bucevska, V. and Misheva, B. H. (2017), “The Determinants of Profitability in the Banking Industry: Empirical Research on Selected Balkan Countries”, Eastern European Economics, 55, 146-167. 
Demirgüç-Kunt; A. and Huizinga, H. (1999), "Determinants of Commercial Bank Interest Margins and Profitability: Some International Evidence”, The World Bank Economic Review, 13(2), 379-408.

Dietrich, A. and Wanzenried, G. (2011), "Determinants of Bank Profitability Before and During the Crisis: Evidence from Switzerland”, Journal of International Financial Markets, Institutions \& Money, 21, 307-327.

Dizgil, E. (2017), “Türkiye’deki Mevduat Bankalarının Karlılığını Etkileyen Mikro Düzeyli

Faktörler Üzerine Ampirik Bir Araştırma”, BDDK Bankacılık ve Finansal Piyasalar Dergisi, 11(2), 31-52.

Kosmidou, K., Pasiouras F., Doumpos, M. and Zopoutiidi, C. (2006), “Assessing Performance Factors in the UK Banking Sector: A Multicriteria Methodology”, Central European Journal of Operations Research, 14(1), 25-44.

Lee, S. (2013), “Financial Crisis, Regulatory Changes and Bank Profit”. Review of European Studies, 5(5), 151-158

Lee, J. Y. and Kim, D. (2013), "Bank Performance and Its Determinants in Korea”, Japan and the World Economy, 27, 83-94.

Madugu, A. H., Ibrahim, M. and Amoah, J. O. (2020), "Differential Effects of Credit Risk and Capital Adequacy Ratio on Profitability of the Domestic Banking Sector in Ghana”, Transnational Corporations Review, 12 (1): 37-52.

Menicucci, E. and Paolucci, G. (2016), “The Determinants of Bank Profitability: Empirical Evidence From European Banking Sector”, Journal of Financial Reporting and Accounting, 14 (1), 86115.

Molyneux, P. and Thornton, J. (1992), “Determinants of European Bank Profitability: A

Note”, Journal of Banking and Finance, 16, 1173-1178.

Nguyen, H. H. (2020), "Impact of Bank Capital Adequacy on Bank Profitability Under Basel II Accord: Evidence From Vietnam”, Journal of Economic Development, 45 (1), 31-46.

Özen, E., and Tetik, M. (2014). “The Effect of Inflation and Interest Rate on Turkish Banking System's Incomes”. International Journal of Economic Perspectives, 8(4). 19-38.

Paleni, H., Hidayat, S. and Jatmiko, D. P. (2017), “Determinants of Profitability: Evidence from Indonesian Firms”, International Journal of Economic Perspectives, 11(3), 1049-1057.

Pasiouras, F. and Kosmidou, K. (2007). "Factors Influencing the Profitability of Domestic and Foreign Commercial Banks in the European Union”, Research in International Business and Finance, 21(2), 222-237.

Pervan, M., Pelivan, I. and Arnerić, J. (2015), "Profit Persistence and Determinants of Bank Profitability in Croatia”, Economic Research-Ekonomska Istraživanja, 28 (1), 284-298.

Saona, P. (2016), “Intra- and Extra-bank Determinants of Latin American Banks' Profitability”, International Review of Economics and Finance, 45, 197-214.

PAGE 17| Journal of Corporate Governance, Insurance, and Risk Management | 2021, VOL. 8, Series. 1 
Spathis, Ch., Kosmidou, K. and Doumpos, M. (2002), “Assessing Profitability Factors in the Greek Banking System. A Multicriteria Methodology”, International Transactions in Operational Research, 9, 517-530.

Staikouras, C.K. and Wood, G.E. (2004), "The Determinants of European Bank Profitability”, International Business and Economic Research Journal, 3 (6), 57-68.

Sufian, F. and Habibullah M. S. (2009), "Determinants of Bank Profitability in a Developing Economy: Empirical Evidence From Bangladesh”, Journal of Business Economics and Management, 10(3), 207-217.

Torres-Reyna, O. (2010), “Getting Started in Fixed/Random Effects Models Using R”, Princeton University, available at: http://dss.princeton.edu/training/ (accessed 15 November 2020). 